Research Paper

\title{
Chlorophytum borivilianum Root Extract Maintains near Normal Blood Glucose, Insulin and Lipid Profile Levels and Prevents Oxidative Stress in the Pancreas of Streptozotocin-Induced Adult Male Diabetic Rats
}

\author{
Nelli Giribabu1, Kilari Eswar Kumar², Somesula Swapna Rekha³, Sekaran Muniandy4, Naguib Salleh ${ }^{\circledR}$ \\ 1. Dept of Physiology, Faculty of Medicine, University of Malaya, 50603 Kuala Lumpur, Malaysia. \\ 2. Pharmacology Division, A.U. College of Pharmaceutical Sciences, Andhra University, Visakhapatnam-530 003, Andhra Pradesh, India. \\ 3. Department of Zoology, Sri Venkateswara University, Tirupati - 517502, Andhra Pradesh, India. \\ 4. Department of Molecular Medicine, Faculty of Medicine, University of Malaya, Kuala Lumpur, Malaysia.
}

$\triangle$ Corresponding author: E-mail: naguib.salleh@yahoo.com.my. Tel: 0060379677532 Fax: 0060379674772.

(C) Ivyspring International Publisher. This is an open-access article distributed under the terms of the Creative Commons License (http:/ /creativecommons.org/ licenses/by-nc-nd/3.0/). Reproduction is permitted for personal, noncommercial use, provided that the article is in whole, unmodified, and properly cited.

Received: 2014.03.09; Accepted: 2014.06.28; Published: 2014.09.03

\begin{abstract}
The effect of $C$. borivilianum root on blood glucose, glycated hemoglobin (HbAlc), insulin and lipid profile levels in diabetes mellitus are not fully understood. This study therefore investigated the effect of $C$. borivilianum root on the above parameters and oxidative stress of the pancreas in diabetes. Methods: $C$. borivilianum root aqueous extract ( 250 and $500 \mathrm{mg} / \mathrm{kg} / \mathrm{day}$ ) was administered to streptozotocin (STZ)-induced male diabetic rats for 28 days. Body weight, blood glucose, HbA Ic, insulin, lipid profile levels and glucose homeostasis indices were determined. Histopathological changes and oxidative stress parameters i.e. lipid peroxidation (LPO) and antioxidant enzymes activity levels of the pancreas were investigated. Results: $C$. borivilianum root extract treatment to diabetic rats maintained near normal body weight, blood glucose, HbAlc, lipid profile and insulin levels with higher HOMA- $\beta$ cell functioning index, number of Islets/pancreas, number of $\beta$-cells/Islets however with lower HOMA-insulin resistance (IR) index as compared to non-treated diabetic rats. Negative correlations between serum insulin and blood glucose, $\mathrm{HbAlc}$, triglyceride (TG) and total cholesterol (TC) levels were observed. $C$. borivilianum root extract administration prevented the increase in lipid peroxidation and the decrease in activity levels of superoxide dismutase (SOD), catalase (CAT) and glutathione peroxidase (GPx) with mild histopathological changes in the pancreas of diabetic rats. Conclusions: $C$. borivilianum root maintains near normal levels of these metabolites and prevented oxidative stress-induced damage to the pancreas in diabetes.
\end{abstract}

Key words: Chlorophytum borivilianum, diabetes, glucose, lipid profile, pancreas, oxidative stress.

\section{Introduction}

Diabetes mellitus (DM) is a chronic metabolic disorder characterized by hyperglycemia [1]. As a consequence, diabetics have high risk of developing metabolic related complications such as ketoacidosis, hyperosmolar non-ketotic coma (HONK) [2] , atherosclerosis [3], coronary artery disease [4] and pancreatitis [5]. These increased risks were due to co-existence of hyperlipidemia, which was characterized by hy- pertriglyceridemia, reduced high-density lipoprotein (HDL) and increased low density lipoprotein (LDL) [6] cholesterol levels.

Oxidative stress plays important role in the pathogenesis of diabetes and its complications [7]. Oxidative stress is caused by increased free radical formation, which were generated through several mechanisms such as glucose auto-oxidation, protein 
glycosylation and accumulation of advanced glycation end products (AGEs) [8]. Oxidative stress could affect pancreatic $\beta$-cells [9] which could be destroyed through a direct insult by the free radicals [10]. Abnormally high levels of reactive oxygen species (ROS) in the pancreas and low levels of antioxidant defense mechanisms could lead to increased oxidative damage which causes reduced insulin secretion [11].

Chlorophytum borivilianum, commonly known as Safed Musli, is a highly valued medicinal plant in India and Southeast Asia. This plant has been shown to possess anticancer, antimicrobial, antifungal, antiulcer, antipyretic, antiarthritic and immunomodulatory activities [12]. Preliminary findings by Panda et al, [13] and Mujeeb et al, [14] reported that $C$. borivilianum could induce acute reduction of blood glucose levels in diabetic rats. Despite of these reports, the effect of long-term administration of $C$. borivilianum root on blood glucose, lipid profiles and insulin levels are currently unknown., Kenjale et al, [15] reported that $C$. borivilianum root aqueous extract can cause significant reduction in blood glucose, TG and cholesterol levels in rats exposed to cold stress as well as displays in-vitro anti-oxidant activity which could help to protect against oxidative stress.

We hypothesized that $C$. borivilianum root was able to prevent impairment of blood glucose, lipid profile and insulin levels and damage to the pancreas due to increased oxidative stress in diabetes. This study therefore aimed to investigate $C$. borivilianum root extract effect on blood glucose, HbA1c, lipid profile, insulin levels and glucose homeostasis indices as well as oxidative stress parameters (lipid peroxidation product-LPO and activity levels of antioxidant enzymes) in the pancreas of diabetic rats. In addition, the histopathological changes of the pancreas in diabetic rats following treatment with the root extract were also investigated.

\section{Materials and Methods}

\section{Drugs and Chemicals}

Streptozotocin was purchased from Sigma Aldrich (St. Louis, MO, USA). All other chemicals were analytical grade.

\section{Plant Collection and Preparation of Plant Extract}

Dried roots of C. borivilianum were procured from Nandan Agro Farms Pvt. Ltd. (Hyderabad, Andhra Pradesh, India) and authenticated by Dr. K. Madhava Chetty, Botanist, Sri Venkateswara University, Tirupati, India. The roots were deposited at Herbarium, Sri Venkateswara University with voucher number: KLU 96568. Dried roots were cut into small pieces and grounded into a fine powder. The root powder $(1000 \mathrm{~g})$ was subjected to cold maceration in $2 \mathrm{~L}$ of sterile distilled water for 48 hours at room temperature, filtered into a clean round bottom flask using No. 1 Whatmann Millipore filter paper (0.45 $\mu \mathrm{m}$ Ref HAWP04700, Bedford, MA, USA) and concentrated to dry by using a rotary evaporator (Rotavapor ${ }^{\circledR}, \mathrm{R}-210$, BuchiLaborotechnik, AG, Flawil, Switzerland) at $50 \pm 5^{\circ} \mathrm{C}$ and lyophilized using a freeze-drying system (Telstar, Barcelona, Spain) to yield approximately $38 \mathrm{~g}$ of solid extract $(3.8 \% \mathrm{w} / \mathrm{w})$.

\section{Experimental Animals}

Adult male Wistar rats ( $220 \pm 10 \mathrm{~g}, 90$ days of age) and Swiss albino mice (six weeks old, weighing $23 \pm 2$ $\mathrm{g}$ were obtained from Animal House, Faculty of Medicine, University of Malaya, Kuala Lumpur, Malaysia. The animals were caged under standard environmental conditions of room temperature of $25 \pm$ $2^{\circ} \mathrm{C}$, relative humidity of between $45-55 \%$ and $12 \mathrm{hrs}$ light/ dark cycle. The animals were fed with standard feed pellets (Harlan diet, UK) and tap water ad libitum. Experimental procedures were in accordance with ARRIVE guidelines (Animals in Research: Reporting In-Vivo Experiments) and European Community Guidelines/ EEC Directive, 1986. This study protocol was approved by the Faculty of Medicine, Animal Care and Use Committee, University of Malaya with ethics number: 2013-07-15/FIS/R/NS.

\section{Phytochemical screening}

A qualitative phytochemical evaluation was performed on the aqueous root extract to determine the presence of carbohydrates (Barfoed's test), flavonoids (test of Shinoda), phytosterols (Libermann Buchard test), phenols (ferric chloride test), alkaloids (Dragendorff test), proteins (Biuret test) and saponins (Saponification test) following the methods as described by Harborne [16].

\section{Acute toxicity study}

Acute toxicity study was conducted according to the Organization for Economic Cooperation and Development $(\mathrm{OECD})$ revised up-and-down procedure for acute toxicity testing (OECD guideline 425) [17]. Healthy adult mice were divided into five groups $(\mathrm{n}=$ 6). A single dose of extract at different concentrations $(50,100,500,1,000$, and 2,000 mg/ $\mathrm{kg} \mathrm{bw})$ added in appropriate quantity with $1 \%$ sodium carboxy methyl cellulose (Na-CMC) was given orally by gavage to different group of mice. The animals were allowed free access to food and water. The animals were deprived of food $2 \mathrm{hr}$ before and $4 \mathrm{hr}$ after dosing. Animals were continuously monitored every $4 \mathrm{hrs}$ for their behavioral (alertness, restlessness, irritability, vomiting, fearfulness), neurological (spontaneous 
activity, convulsion, gait, bleeding orifices, touch/pain response) and autonomic (defecation, micturition) profiles. The number of demise mice in each group was recorded after 24-72 hrs. The extract was devoid of any toxic effect to the animals when given at doses up to $2000 \mathrm{mg} / \mathrm{kg}$. Hence, in this study, doses at 250 and $500 \mathrm{mg} / \mathrm{kg}$ were selected. Several studies used mice as a model to investigate dose-related toxic effect of plant extracts prior to their administration in rats $[18,19]$.

\section{Induction of Diabetes}

Hyperglycemia was induced in overnight fasted male rats via a single intraperitoneal injection of STZ dissolved in ice cold citrate buffer $(0.1 \mathrm{M}, \mathrm{pH} 4.5)$ at a dose of $55 \mathrm{mg} / \mathrm{kg}$ [20]. The rats were allowed to drink $5 \%$ sucrose solution overnight after drug injection to overcome hypoglycemia. Diabetes was confirmed from the presence of polydipsia, polyuria and weight loss and also only animals exhibiting fasting glucose level greater than $300 \mathrm{mg} / \mathrm{dL}$ however lower than 400 $\mathrm{mg} / \mathrm{dl}$ three days after STZ injection were used in this study. Treatment with 250 and $500 \mathrm{mg} / \mathrm{kg}$ body weight of $C$. borivilianum root extract [14] was commenced four days after STZ injection and this was considered as day one. The root extract was administered in the form of suspension in 1\% Na-CMC dissolved in distilled water by using an oral gavage tube daily for 28 consecutive days which was regarded as sub-chronic treatment duration [19, 21].

\section{Experimental Design}

The animals were randomly assigned into five experimental groups with six (6) rats per group:

Group I - Control rats- received 1\% Na-CMC vehicle only.

Group II - Diabetic control rats- received 1\% $\mathrm{Na}-\mathrm{CMC}$ vehicle only.

Group III and IV - Diabetic rats treated with $C$. borivilianum root aqueous extract at $250 \& 500 \mathrm{mg} / \mathrm{kg}$ body weight respectively.

Group V- Diabetic rats treated with a standard anti-diabetic agent, glibenclamide [22, 23] at 600 $\mu \mathrm{g} / \mathrm{kg}$ body weight.

Fasting blood samples of rats were collected once weekly from the retro-orbital plexus under light ether anesthesia into a collection tube. At the end of the experimental period (day $28^{\text {th }}$ ), overnight fasted rats were weighed and then sacrificed with intraperitoneal injection of pentobarbital sodium $(60 \mathrm{mg} / \mathrm{kg})$ anesthesia followed by cervical dislocation. Blood was immediately withdrawn via heart puncture into the collection tubes and serum was separated by centrifugation (Thermo Scientific, Model 75005286, USA) at $2000 \times \mathrm{g}$ for $15 \mathrm{~min}$ for biochemical and hormone analyses and stored at $-20^{\circ} \mathrm{C}$ until future use.

\section{Fasting Blood Glucose (FBG) Measurement}

FBG level was measured at day $0^{\text {th }}, 7^{\text {th }}, 14^{\text {th }}, 21^{\text {st }}$ and $28^{\text {th }}$. of the experimental period. Glucose levels were estimated with glucose oxidase/peroxidase kit (BioSystems S.A. Costa Brava 30, Barcelona, Spain). In principle, glucose was oxidized to gluconate and hydrogen peroxide, with the product coupled with 4-faminoantipyrine and phenol to generate quinoneimine. A colored complex was produced which was proportional to glucose concentration in the sample. Intensity of the color changes was measured at absorbance wavelength of $500 \mathrm{~nm}$ with an automated analyzer Dimension RxL Max Integrated Chemistry System (Siemens Healthcare Diagnostics Inc. Deerfield, IL, USA).

\section{Measurement of Glycosylated Hemoglobin (HbAlc) Levels}

Glycosylated hemoglobin in whole blood was estimated by using an automated analyzer Dimension RxL Max Integrated Chemistry System (Siemens Healthcare Diagnostics Inc. Deerfield, IL, USA).

\section{Measurement of Serum Insulin levels}

Serum insulin levels were estimated by using enzyme-linked immunosorbent assay (ELISA) kit (EIA-2048, 96 wells, DRG Instruments $\mathrm{GmbH}$, Marburg, Germany) according to the manufacturer's guideline. Briefly, during incubation, insulin in the sample reacts with peroxidase-conjugated anti-insulin antibodies which bound to the micro-titer wells. A sample washing step removes the unbound enzyme-labeled antibody. The bound conjugate was detected by the reaction with $3,3^{\prime}, 5$, $5^{\prime}$-tetramethylbenzidine. The reaction was stopped by adding acid to give a colorimetric end-point and optical density was measured by using a micro plate auto reader (iMark ${ }^{\mathrm{TM}}$; Bio-Rad, Hercules, CA, USA) at a wavelength of $450 \mathrm{~nm}$.

\section{Determination of Lipid Profile Levels}

Serum lipid profile levels including high density lipoprotein (HDL), total cholesterol (TC) and triglyceride (TG) were measured by using an automated analyzer Dimension RxL Max Integrated Chemistry System (Siemens Healthcare Diagnostics Inc. Deerfield, IL, USA). Serum low density lipoprotein (LDL) and very low density lipoprotein (VLDL) were estimated based on Friedewald formula [24]:

$$
\begin{gathered}
\text { LDL }=\text { Total Cholestrol }-\mathrm{HDL}-\left(\frac{\mathrm{TG}}{5}\right) \\
\text { VLDL }=\frac{\mathrm{TG}}{5}
\end{gathered}
$$




\section{Homeostatic Model Assessment (HOMA)}

Insulin resistance index (HOMA-IR) and $\beta$-cell function index (HOMA- $\beta$ cell function) were calculated according to the following formulas [25].

$$
\begin{gathered}
\text { HOMA }- \text { IR }=\frac{\text { Fasting insulin } \times \text { Fasting glucose }}{405} \\
\text { HOMA }-\beta \text { Cell Function }=\frac{360 \times \text { Fasting insulin }}{\text { Fasting glucose }-63}
\end{gathered}
$$

\section{Pancreas Histology and Morphometric Analyses}

Following sacrificed, rats' pancreas was immediately harvested and fixed overnight in $10 \%$ formalin followed by paraffin embedding. Paraffin-embedded sections were cut into $5 \mu \mathrm{m}$ thickness by using a microtome (Histo-line laboratories, ARM-3600, Viabrembo, Milan, Italy). The sections were deparaffinized by immersion in xylene for $20 \mathrm{~min}$, and then dropped into ethanol solution at decreasing concentrations $(100 \%, 95 \%, 90 \%$ and $80 \%)$, for 5 min each. The sections were then stained with hematoxylin and eosin. Histopathological changes of the pancreas were viewed and micro-graphed under a phase contrast microscope with an attached photograph machine (Nikon H600L, Tokyo, Japan). The morphometric analyses of the pancreas were performed by using Image J software (Image J 1.39f, NIH-Bethesda, MD, USA). From each group, six histological sections were examined at different magnifications to obtain the average of (1): number of islets of Langerhans/pancreas, (2): diameter of Islets of Langerhans, (3): number of $\beta$-cells/ Islets of Langerhans and 4): diameter of $\beta$-cells.

\section{Estimation of Pancreas Lipid Peroxidation Product (LPO)}

LPO was estimated by thiobarbituric acid (TBA) reaction with malondialdehyde (MDA), a product formed due to peroxidation of membrane lipids [26]. In brief, $2.5 \mathrm{ml}$ of pancreas homogenate, $0.5 \mathrm{ml}$ of $0.9 \%$ $\mathrm{NaCl}, 1.0 \mathrm{ml}$ of $20 \% \mathrm{w} / \mathrm{v}$ TCA were added. The content was centrifuged for 20 minutes in a refrigerated centrifuge at $4000 \times \mathrm{g}$. To $1.0 \mathrm{ml}$ of supernatant, 0.25 $\mathrm{ml}$ of TBA reagent was added and the content was incubated at $95^{\circ} \mathrm{C}$ for $1 \mathrm{hr}$ then cooled under tap water prior to adding $1 \mathrm{ml}$ of $\mathrm{n}$-butanol. After a thorough mixing, the content was again centrifuged for 15 minutes at $4000 \times \mathrm{g}$ in a refrigerated centrifuge. The organic layer was transferred into a clear tube and the absorbance was measured at $532 \mathrm{~nm}$ using a spectrophotometer (UV-1700, Shimadzu, Kyoto, Japan). The rate of lipid peroxidation was expressed as $\mu$ moles of MDA formed/gram wet weight of tissue.

\section{Estimation of Pancreas Superoxide Dismutase (SOD) Activity}

SOD enzyme activity of the homogenates was assayed according to the method of Misra and Fridovich [27]. The assay procedure involved inhibition of epinephrine auto-oxidation in alkaline medium ( $\mathrm{pH} 10.2)$ to adrenochrome, which was markedly inhibited in the presence of this enzyme. To $0.5 \mathrm{ml}$ of supernatant, $1.5 \mathrm{ml}$ of carbonate buffer $(0.05 \mathrm{M}, \mathrm{pH}$ 10.2 ) and $0.5 \mathrm{ml}$ of ethylene-diamine-tetra acetic acid (EDTA) solution $(0.49 \mathrm{M})$ were added. The reaction was initiated by adding $0.4 \mathrm{ml}$ epinephrine $(3 \mathrm{mM})$. Changes in the absorbance were recorded at $480 \mathrm{~nm}$ for $1 \mathrm{~min}$ at $15 \mathrm{sec}$ interval, $3 \mathrm{~min}$ each by using a spectrophotometer (UV-1700, Shimadzu, Kyoto, Japan). SOD activity levels were expressed as the amount of enzymes that inhibit oxidation of epinephrine by $50 \%$, which was equal to $1 \mathrm{U}$ per milligram of protein.

\section{Estimation of Pancreas Catalase (CAT) Activity}

CAT enzyme activity of the homogenates was determined on the basis of hydrogen peroxide decomposition [28]. The reaction solution contained $2.5 \mathrm{ml}$ of $50 \mathrm{mmol}$ phosphate buffers ( $\mathrm{pH} 5.0$ ), $0.4 \mathrm{ml}$ of $5.9 \mathrm{mmol} \mathrm{H}_{2} \mathrm{O}_{2}$ and $0.1 \mathrm{ml}$ enzyme extract. The reaction was initiated by addition of the enzyme. Changes in the absorbance of the reaction solution at $240 \mathrm{~nm}$ were noted every $30 \mathrm{~s}$ and was determined by using a spectrophotometer (UV-1700, Shimadzu, Kyoto, Japan). The activity levels of this enzyme were expressed in $\mu \mathrm{mol}$ of hydrogen peroxide $\left(\mathrm{H}_{2} \mathrm{O}_{2}\right)$ metabolized/mg protein/min.

\section{Assay of Pancreas Glutathione Peroxidase (GPx) Activity}

The activity levels of GPx in the homogenates were determined according to the method by Rotruck \& Pope [29]. The reaction mixture consist of $0.2 \mathrm{ml}$ of $0.8 \mathrm{mM}$ EDTA, $0.1 \mathrm{ml}$ of $10 \mathrm{mM}$ sodium azide, $0.1 \mathrm{ml}$ of $2.5 \mathrm{mM} \mathrm{H}_{2} \mathrm{O}_{2}, 0.2 \mathrm{ml}$ of glutathione (GSH), $0.4 \mathrm{ml}$ of $0.4 \mathrm{mM}$ phosphate buffer ( $\mathrm{pH} 7.0$ ) and $0.2 \mathrm{ml}$ of homogenate incubated at $37{ }^{\circ} \mathrm{C}$ for 10 minutes. The reaction was arrested by addition of $0.5 \mathrm{ml}$ of $10 \%$ TCA and the tubes were centrifuged at $2000 \times \mathrm{rpm}$. To the supernatant, $3.0 \mathrm{ml}$ of $0.3 \mathrm{M}$ disodium hydrogen phosphate and $1.0 \mathrm{ml}$ of DTNB were added and the color developed was immediately read at $420 \mathrm{~nm}$ by using a spectrophotometer (UV-1700, Shimadzu, Kyoto, Japan). The activity levels of GPx were expressed as $\mu \mathrm{Mol}$ of GSH consumed/mg protein $/ \mathrm{min}$. 


\section{Statistical Analyses}

Statistical differences were evaluated by analysis of variance (ANOVA) followed by Duncan's new multiple-range and Student's t-tests. A probability level of less than $0.05(\mathrm{p}<0.05)$ was considered as significant. Post-hoc statistical power analysis was performed and all the values obtained were $>0.8$ which indicate adequate sample size. Meanwhile, Shapiro-Wilk test was performed and all values obtained were $>0.05$ which indicate that these data were normally distributed.

\section{Results}

\section{Phytochemical screening}

Qualitative phytochemical screening of the aqueous extract of $C$. borivilianum root showed the presence of carbohydrates, proteins, phytosterols, alkaloids, flavonoids and phenolic acids (data not shown).

\section{Acute toxicity studies}

Animals showed good tolerance to the tested single dose of aqueous extract of $C$. borivilianum root up to doses as high as $2000 \mathrm{mg} / \mathrm{kg}$ which were found to be non-lethal. The highest dose of the extract did not present any noticeable signs of toxicity and mortality until the end of the study period.

\section{Body Weight Changes}

Figure 1 shows the effect of $C$. borivilianum root aqueous extract or glibenclamide on body weight in diabetic rats. Our findings indicate that the final body weight of diabetic rats was significantly reduced (25.93\%) as compared to initial body weight, and was $29.45 \%$ lower than the final body weight of normal, non-diabetic rats. Administration of $C$. borivilianum root aqueous extract at 250 and $500 \mathrm{mg} / \mathrm{kg} /$ day caused no significant weight loss in diabetic rats as compared to normal, non-diabetic rats.

\section{Changes in Fasting Blood Glucose (FBG) Levels}

Figure 2 shows the effect of $C$. borivilianum root aqueous extract or glibenclamide on diabetic rats' FBG levels at weekly interval within 28 days treatment period. In non-treated diabetic rats, FBG levels were persistently higher than normal, non-diabetic rats. In diabetic rats, FBG levels began to decline beginning from day $7^{\text {th }}$, decline further at day $14^{\text {th }}$ and reached the lowest at day $28^{\text {th }}$ of $C$. borivilianum root aqueous extract or glibenclamide treatments. No significant difference in FBG levels were noted between treatment with $500 \mathrm{mg} / \mathrm{kg} /$ day C. borivilianum root aqueous extract and glibenclamide at weekly interval.

\section{Changes in Serum HbAlc Levels}

Figure 3A shows the effect of $C$. borivilianum root aqueous extract or glibenclamide on serum $\mathrm{HbA1c}$ levels in diabetic rats. Our findings indicate that serum $\mathrm{HbA} 1 \mathrm{c}$ levels were 2.71 fold higher in diabetic rats as compared to normal, non-diabetic rats. Treatment with $C$. borivilianum root aqueous extract at $250 \mathrm{mg} / \mathrm{kg} /$ day and $500 \mathrm{mg} / \mathrm{kg} /$ day resulted in $28.25 \%$ and $44.88 \%$ lower $\mathrm{HbA} 1 \mathrm{c}$ levels respectively as compared to non-treated diabetic rats. No significant changes in serum $\mathrm{HbA1c}$ levels were noted between rats treated with $500 \mathrm{mg} / \mathrm{kg} /$ day C. borivilianum root aqueous extract and glibenclamide.

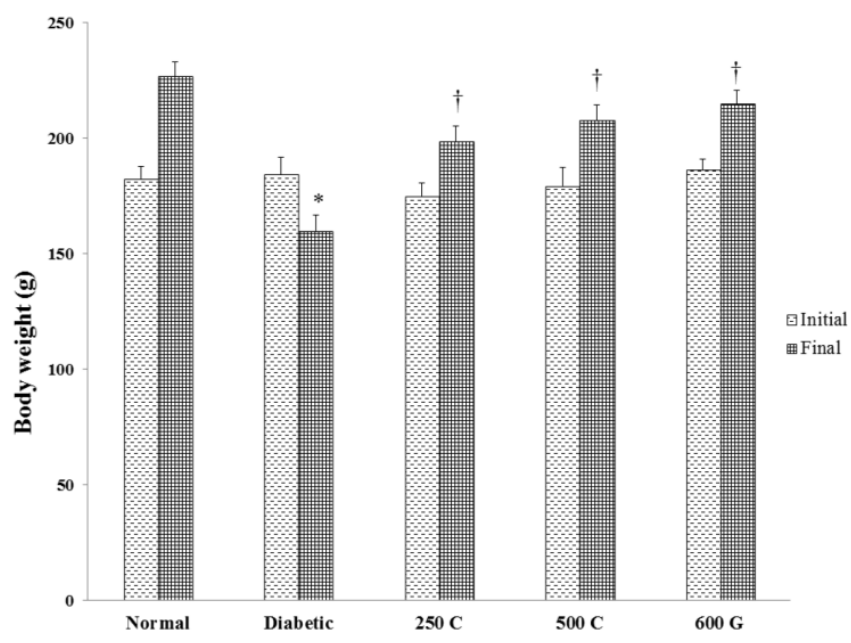

Figure I: Effect of $C$. borivilianum root aqueous extract treatment on initial and final body weight in different experimental groups. Significantly lower body weight was noted in diabetic rats as compared to normal, non-diabetic rats. $C$. borivilianum root aqueous extract and glibenclamide treatments prevented body weight loss in diabetic rats. $n=6$ rats per group. ${ }^{*} p<0.05$ as compared to initial body weight. $250 \mathrm{C}$ : $250 \mathrm{mg} / \mathrm{kg} /$ day $C$. borivilianum root aqueous extract, $500 \mathrm{C}$ : $500 \mathrm{mg} / \mathrm{kg} / \mathrm{day}$ C. borivilianum root aqueous extract; $600 \mathrm{G}: 600 \mathrm{\mu g} / \mathrm{kg} / \mathrm{day}$ glibenclamide.

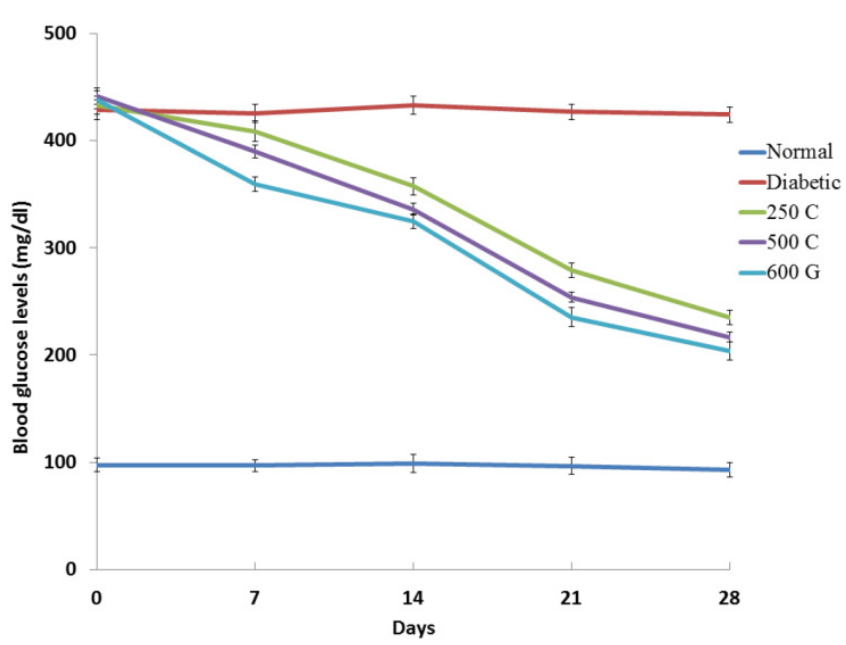

Figure 2: Effect of $C$. borivilianum root aqueous extract treatment on the FBG level at weekly interval in different experimental groups within 28-days of treatment. No significant changes in FBG level were noted in normal, non-diabetic rats. In diabetic rats, FBG was persistently high throughout 28 days. A significantly lower FBG level was noted beginning from day 7 of $C$. borivilianum root aqueous extract and glibenclamide treatments. Near normal FBG was observed in these treatment groups at day 28 . $\mathrm{n}=6$ rats per group. $250 \mathrm{C}: 250 \mathrm{mg} / \mathrm{kg} / \mathrm{day} C$. borivilianum root aqueous extract, $500 \mathrm{C}: 500 \mathrm{mg} / \mathrm{kg} /$ day $C$. borivilianum root aqueous extract; 600G: $600 \mu \mathrm{gg} / \mathrm{kg} /$ day glibenclamide. 


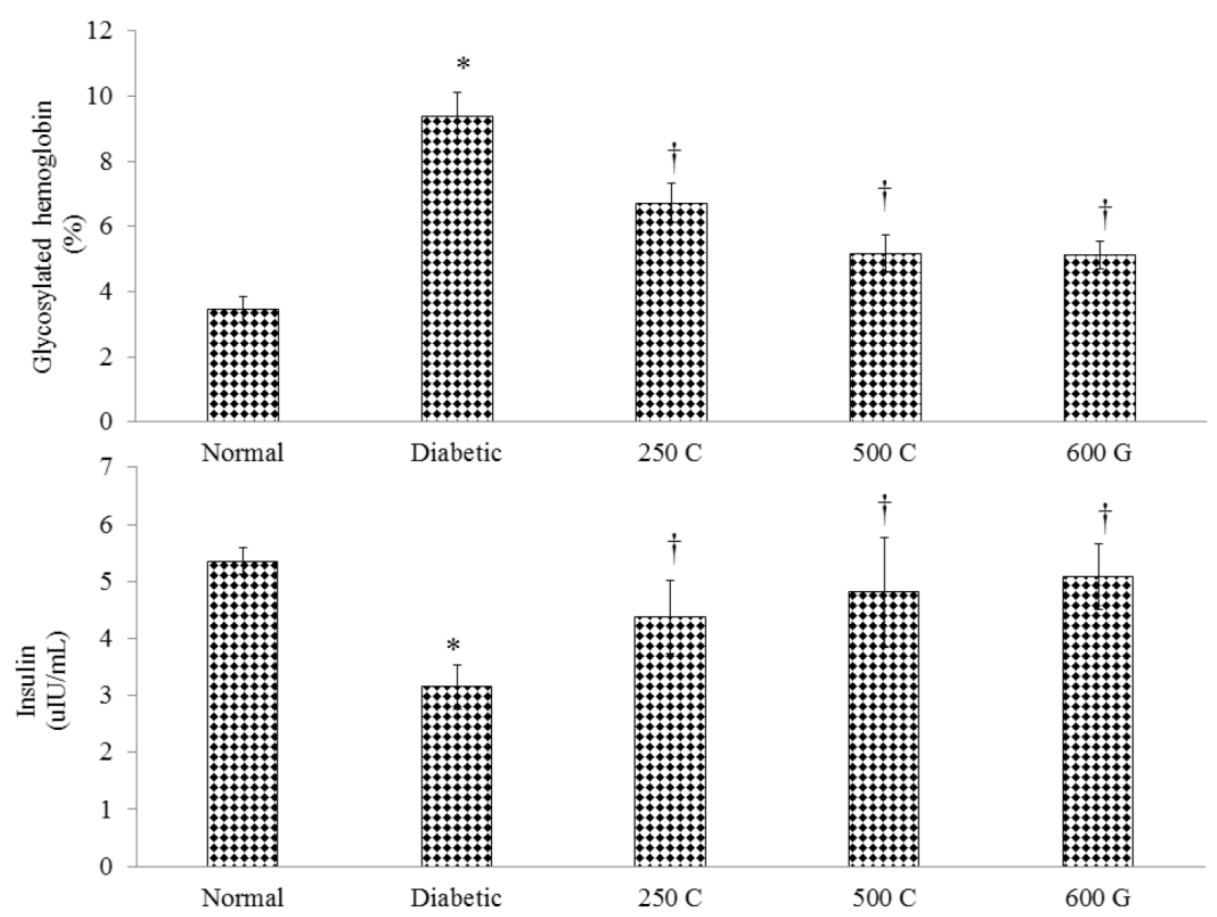

Figure 3: A) Effect of $C$. borivilianum root aqueous extract treatment on HbAlc level in different experimental groups. The level of $\mathrm{HbA}$ Ic was the highest in diabetic group. Treatment with $C$. borivilianum root aqueous extract or glibenclamide caused significantly lower $\mathrm{HbA} / \mathrm{c}$ levels as compared to the non-treated diabetic rats. $\mathrm{n}=6$ rats per treatment group. ${ }^{*} \mathrm{p}<0.05$ as compared to normal, non-diabetic rats. $\dagger \mathrm{P}<0.05$ as compared to non-treated diabetic rats. $250 \mathrm{C}: 250 \mathrm{mg} / \mathrm{kg} / \mathrm{day} C$. borivilianum root aqueous extract, 500C: $500 \mathrm{mg} / \mathrm{kg} /$ day C. borivilianum root aqueous extract; $600 \mathrm{G}: 600 \mu \mathrm{g} / \mathrm{kg} /$ day glibenclamide. B) Effect of $C$. borivilianum root aqueous extract treatment on serum insulin levels in different experimental groups. The level of insulin is the lowest in diabetic rats. Treatment with $C$. borivilianum root aqueous extract or glibenclamide caused significantly higher serum insulin levels as compared to the non-treated diabetic rats. $\mathrm{n}=6$ rats per treatment group. ${ }^{*} \mathrm{p}<0.05$ as compared to normal, non-diabetic rats. $\nmid \mathrm{P}<0.05$ as compared to non-treated diabetic rats. $250 \mathrm{C}: 250 \mathrm{mg} / \mathrm{kg} /$ day C. borivilianum root aqueous extract, $500 \mathrm{C}: 500 \mathrm{mg} / \mathrm{kg} / \mathrm{day} C$. borivilianum root aqueous extract; 600G: $600 \mu \mathrm{g} / \mathrm{kg} /$ day glibenclamide.

\section{Changes in Serum Insulin Levels}

Figure 3B shows the effect of $C$. borivilianum root aqueous extract or glibenclamide on serum insulin levels in diabetic rats. Our findings indicate that the levels of serum insulin were the lowest in diabetic rats $(41.23 \%)$ as compared to normal, non-diabetic rats. Treatment with $250 \mathrm{mg} / \mathrm{kg} /$ day and $500 \mathrm{mg} / \mathrm{kg} /$ day C. borivilianum root aqueous extract resulted in higher insulin levels $(39.05 \%$ and $52.69 \%$ respectively) as compared to non-treated diabetic rats. No significant difference was noted in serum insulin levels between treatments with $C$. borivilianum root aqueous extract and glibenclamide.

\section{Changes in Lipid Profile Levels}

Table 1 shows the effect of $C$. borivilianum root aqueous extract or glibenclamide on serum lipid profile levels in diabetic rats. Our findings indicate that TC, TG, VLDL, and LDL levels were 100.4\%, 56.2\%, $56.3 \%$ and $1006.2 \%$ higher respectively in diabetic rats as compared to normal, non-diabetic rats. However, in diabetic rats, HDL levels were lower $(61.96 \%)$ than normal, non- diabetic rats. Treatments of diabetic rats with C. borivilianum root aqueous extract at 250 and $500 \mathrm{mg} / \mathrm{kg} /$ day resulted in the followings: $15.95 \%$ and $29.21 \%$ lower TC, $16.96 \%$ and $20.57 \%$ lower TG and VLDL, $27.71 \%$ and $52.65 \%$ lower LDL respectively as compared to non-treated diabetic rats. $52.15 \%$ and $89.04 \%$ higher HDL level was noted respectively in diabetic rats receiving $250 \mathrm{mg} / \mathrm{kg} /$ day and $500 \mathrm{mg} / \mathrm{kg} /$ day C. borivilianum root extract treatment as compared to non-treated diabetic rats. Glibenclamide treatment resulted in lower TC, TG, VLDL and LDL levels but higher HDL levels as compared to the treatment with $500 \mathrm{mg} / \mathrm{kg} /$ day $C$. borivilianum root aqueous extract.

\section{Correlation between Serum Insulin Levels and Metabolite Parameters}

Figure 4 shows the correlation between serum insulin and blood glucose (on day $28^{\text {th }}$ ), HbA1c, TG and TC levels. There were strong negative correlations between serum insulin and blood metabolite parameters (FBG, HbA1c, TG and TC) with correlation coefficients, (r) of $0.9692,0.9848,0.9817$ and 0.9618 respectively. 
Table I: Effect of $C$. borivilianum root aqueous extract treatment on serum levels of total cholesterol, triglycerides, HDL, LDL and VLDL in different experimental groups.

\begin{tabular}{|c|c|c|c|c|c|}
\hline \multirow[t]{2}{*}{ Parameters } & \multirow[t]{2}{*}{ Normal } & \multirow[t]{2}{*}{ Diabetic } & \multicolumn{3}{|l|}{ Diabetic } \\
\hline & & & $\begin{array}{l}250 \mathrm{mg} / \mathrm{kg} \\
\text { C. borivilianum }\end{array}$ & $\begin{array}{l}500 \mathrm{mg} / \mathrm{kg} \\
\text { C. borivilianum }\end{array}$ & $\begin{array}{l}600 \mu \mathrm{g} / \mathrm{kg} \\
\text { glibenclamide }\end{array}$ \\
\hline Total cholesterol (mg/dl) & $58.56 \pm 3.85$ & $117.36^{*} \pm 5.83$ & $98.64^{\#} \pm 3.24$ & $83.07 \# \pm 5.95$ & $75.16^{\#} \pm 3.14$ \\
\hline Triglycerides (mg/dl) & $74.35^{a} \pm 2.63$ & $116.15^{*} \pm 4.75$ & $96.45^{\#} \pm 5.96$ & $92.25^{\#} \pm 3.35$ & $83.63^{\#} \pm 3.34$ \\
\hline HDL (mg/dl) & $36.46 \pm 2.34$ & $14.15^{\star} \pm 1.53$ & $21.53^{\#} \pm 2.48$ & $26.75^{\#} \pm 1.43$ & $29.52^{\#} \pm 2.72$ \\
\hline LDL (mg/dl) & $7.23 \pm 1.37$ & $79.98^{*} \pm 2.83$ & $57.82^{\#} \pm 2.42$ & $37.87^{\#} \pm 2.56$ & $28.92^{\#} \pm 1.64$ \\
\hline VLDL (mg/dl) & $14.87 \pm 1.55$ & $23.23^{*} \pm 1.36$ & $19.29^{\#} \pm 1.64$ & $18.45^{\# \pm} \pm 1.85$ & $16.72^{\#} \pm 1.72$ \\
\hline
\end{tabular}

The value represents means \pm S.D. for 6 rats per group. ${ }^{*} p<0.01$ compared to normal non-diabetic rats, ${ }^{*} p<0.01$ as compared to diabetic rats.
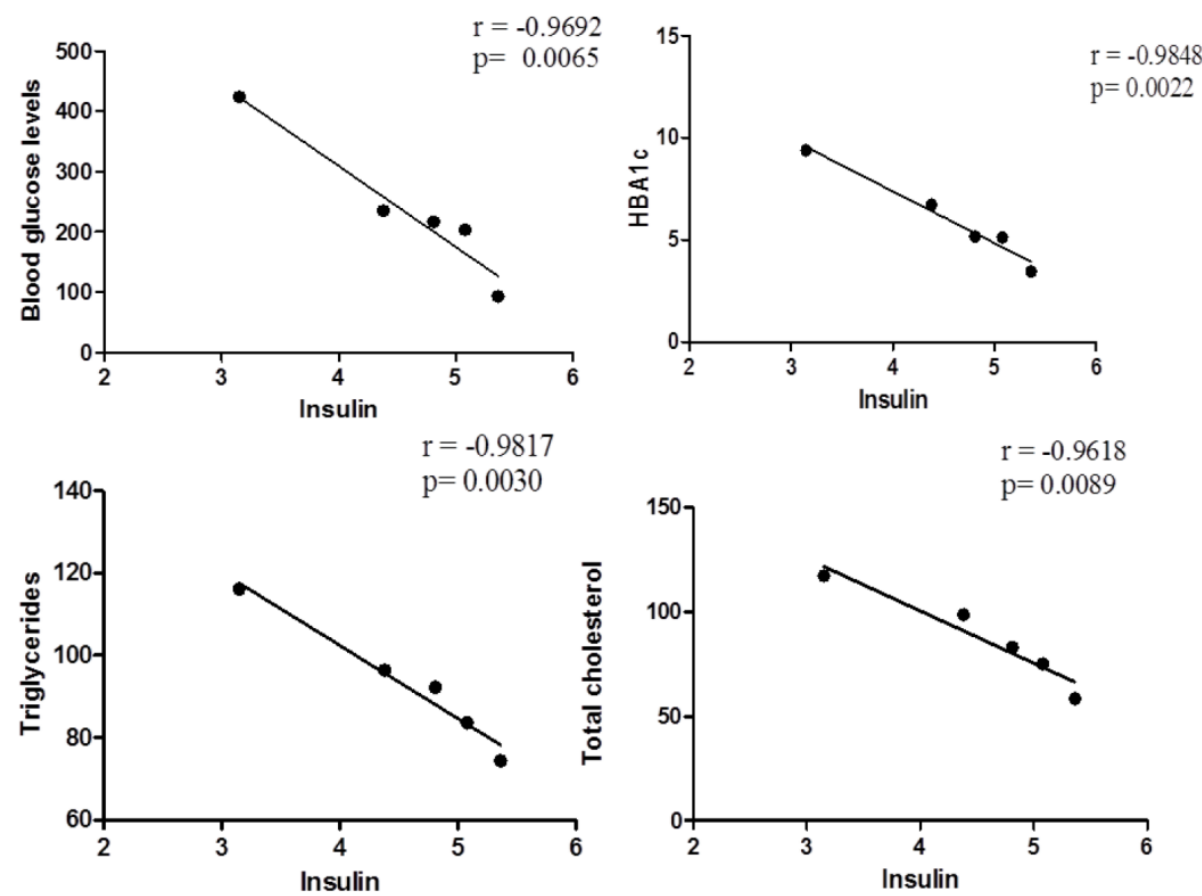

Figure 4: Correlation between serum insulin levels and (a) blood glucose levels at day 28, (b) HbAlc, (c) triglyceride and (d) total cholesterol levels. There are strong negative correlations $(r>0.90)$ between serum insulin levels and the studied parameters indicating insulin-dependent changes.

\section{Histopathological Changes of the Pancreas}

Figure 5 shows the images of the pancreas of non-diabetic, non-treated diabetic and diabetic rats treated with $C$. borivilianum root aqueous extract or glibenclamide. Normal appearance of Islets of Langerhans and acinar cells were seen in normal, non-diabetic rats. Histopathological changes as featured by destruction of the Islets, blood-filled interlobular duct and disorganized acinar cells were seen in STZ-induced diabetic rats. Milder histopathological changes as indicated by higher number of Islets/pancreas, $\beta$-cells/Islets ratio and diameter of Islets and $\beta$-cells were seen following $C$. borivilianum root aqueous extract or glibenclamide treatments in diabetic rats as compared to non-treated diabetic rats.

\section{Morphometric Analyses of the Pancreas}

Table 2 shows average number of Islets of Langerhans, diameter of Islets, number of $\beta$-cells within an Islet and $\beta$-cell diameter in normal, non-treated diabetic and diabetic rats treated with $C$. borivilianum root aqueous extract at 250 and $500 \mathrm{mg} / \mathrm{kg} /$ day or glibenclamide. The average number of Islets was significantly reduced in diabetic rats $(60.43 \%)$ as compared to normal, non-diabetic rats. In parallel, diameter of Islets, number of $\beta$-cells per Islet and diameter of $\beta$-cells were also reduced by $41.23 \%$, $53.08 \%$ and $30.9 \%$ respectively as compared to normal, non-diabetic rats. Treatment with 250 and $500 \mathrm{mg} / \mathrm{kg} /$ day C. borivilianum root aqueous extract resulted in higher number of Islets $(71.27 \%$ and $105.51 \%)$, diameter of Islets $(24.13 \%$ and $47.82 \%)$, number of $\beta$-cells per Islet $(45.47 \%$ and $67.77 \%)$ and diameter of $\beta$-cells $(16.82 \%$ and $22.15 \%)$ respectively as compared to non-treated diabetic rats. Glibenclamide treatment resulted in $118.67 \%$, 57.61\%, $71.95 \%$ and $29.13 \%$ higher number of Islets, Islet diameter, number of $\beta$-cells per Islet and $\beta$-cell diameter respectively as compared to non-treated diabetic rats. 


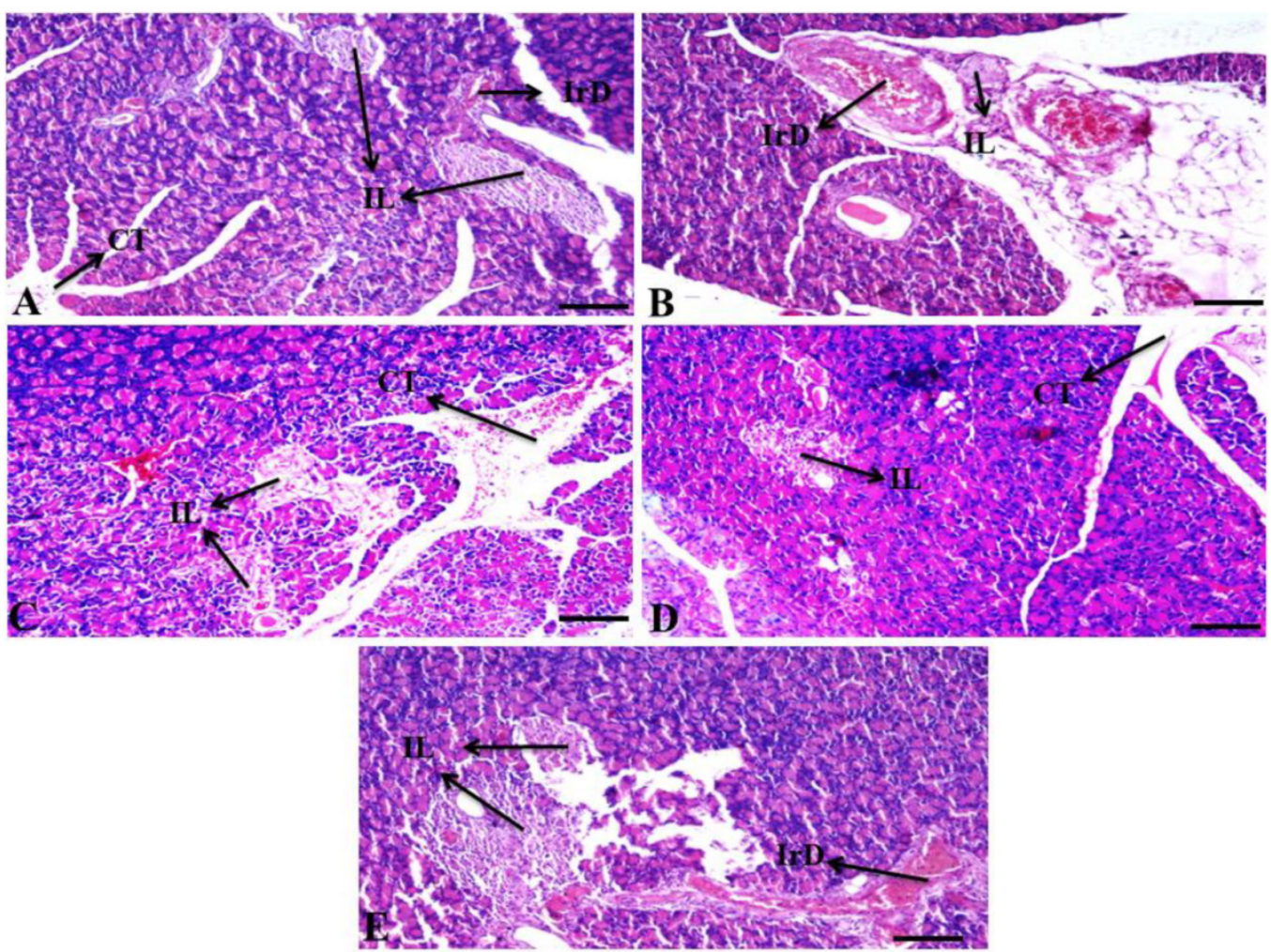

Figure 5: Representative high magnification image of pancreas in different experimental groups. A) normal, non-diabetic rats, B) STZ-induced diabetic rats, C) $250 \mathrm{mg} / \mathrm{kg} /$ day C. borivilianum root aqueous extract treatment, D) $500 \mathrm{mg} / \mathrm{kg} /$ day C. borivilianum root aqueous extract treatment and E) glibenclamide treatment. Lower number and size of Islets of Langerhans was observed in diabetic rats as compared to non-diabetic rats. C. borivilianum root aqueous extract treatment caused higher Islet size and numbers in diabetic rats. IrD - Interlobular duct, CT - Connective tissue, BV- Blood vessel, IL - Islet of Langerhans. Scale bar = 50 $\mu \mathrm{m}$.

Table 2: Effect of $C$. borivilianum root aqueous extract treatment on the number of Islets/pancreas, diameter of Islets, number of $\beta$-cells/lslets and diameter of $\beta$-cells in different experimental groups.

\begin{tabular}{|c|c|c|c|c|c|}
\hline \multirow[t]{2}{*}{ Parameters } & \multirow[t]{2}{*}{ Normal } & \multirow[t]{2}{*}{ Diabetic } & \multicolumn{3}{|l|}{ Diabetic } \\
\hline & & & $250 \mathrm{mg} / \mathrm{kg}$ C. borivilianum & $500 \mathrm{mg} / \mathrm{kg} \mathrm{C.} \mathrm{borivilianum}$ & $600 \mu \mathrm{g} / \mathrm{kg}$ glibenclamide \\
\hline Number of islet of Langerhans/pancreas & $21.56 \pm 1.54$ & $8.53^{*} \pm 0.94$ & $14.61^{\#} \pm 1.46$ & $17.53^{\#} \pm 1.35$ & $18.67 \# \pm 1.73$ \\
\hline Diameter of islet of Langerhans $(\mu \mathrm{m})$ & $143.56 \pm 3.64$ & $84.37^{*} \pm 4.57$ & $104.71^{\#} \pm 3.19$ & $124.69 \# \pm 4.54$ & $132.96^{\#} \pm 3.85$ \\
\hline Number of $\beta$-cells/ islet of Langerhans & $12.78 \pm 0.94$ & $5.74^{*} \pm 0.47$ & $8.35^{\#} \pm 0.59$ & $9.63^{\#} \pm 0.64$ & $9.87 \# \pm 0.56$ \\
\hline Diameter of $\beta$-cells $(\mu \mathrm{m})$ & $5.86 \pm 0.64$ & $4.05^{*} \pm 0.38$ & $4.73^{\#} \pm 0.46$ & $4.94^{\#} \pm 0.79$ & $5.23^{\#} \pm 0.84$ \\
\hline
\end{tabular}

Value represents means \pm S.D. for 6 rats per group. ${ }^{*} \mathrm{p}<0.01$ as compared to normal, non-diabetic rats group, ${ }^{\# p}<0.01$ as compared to diabetic rats.

Table 3: HOMA-IR and HOMA- $\beta$ cell function in different experimental groups.

\begin{tabular}{lllll}
\hline Parameters & Normal & Diabetic & Diabetic & \\
\cline { 3 - 4 } & & & $250 \mathrm{mg} / \mathrm{kg}$ C. borivilianum & $500 \mathrm{mg} / \mathrm{kg} \mathrm{C.} \mathrm{borivilianum}$ \\
\hline HOMA-IR & $1.23 \pm 0.04$ & $3.29^{*} \pm 0.07$ & $2.54^{\#} \pm 0.05$ & $2.57^{\#} \pm 0.08$ \\
HOMA- $\beta$ cell functioning & $64.0 \pm 1.35$ & $3.13^{*} \pm 0.75$ & $9.15^{\#} \pm 0.58$ & $11.26^{\#} \pm 0.47$ \\
\hline
\end{tabular}

The value represents means \pm S.D. for 6 rats per group. ${ }^{*} \mathrm{p}<0.01$ as compared to non-diabetic rats, ${ }^{\#} \mathrm{p}<0.01$ as compared to diabetic rats.

\section{Estimation of HOMA Indices}

Table 3 shows the HOMA indices for insulin resistance (HOMA-IR) and $\beta$-cell function (HOMA- $\beta$ cell) in normal, diabetic rats and diabetic rats treated with 250 and $500 \mathrm{mg} / \mathrm{kg} /$ day C. borivilianum root aqueous extract or glibenclamide. Our findings indicate that HOMA-IR index was $167.47 \%$ higher in diabetic rats as compared to normal, non-diabetic rats.
Meanwhile, HOMA- $\beta$ cell functioning index was 95.11\% lower in diabetic rats as compared to normal, non-diabetic rats. Treatment with $250,500 \mathrm{mg} / \mathrm{kg} /$ day C. borivilianum root aqueous extract or glibenclamide in diabetic rats resulted in $22.79 \%, 21.88 \%$ and $22.49 \%$ lower HOMA-IR index respectively as compared to non-treated diabetic rats. Treatment of diabetic rats with 250 and $500 \mathrm{mg} / \mathrm{kg} /$ day $C$. borivilianum root aqueous extract resulted in higher HOMA- $\beta$ cell 
functioning index (192.33\% and $259.74 \%$ respectively) as compared to non-treated diabetic rats. Glibenclamide treatment resulted in $315.01 \%$ higher HOMA $\beta$-cell functioning index as compared to non-treated diabetic rats.

\section{Pancreas LPO Levels}

Figure 6A shows the effect of $C$. borivilianum root aqueous extract or glibenclamide on the amount of LPO product, MDA in diabetic rats' pancreas. Pancreatic MDA levels were significantly $(p<0.01)$ higher $(163.47 \%)$ in non-treated diabetic rats as compared to normal, non-diabetic rats. However, the levels of MDA were $31.83 \%$ lower following $250 \mathrm{mg} / \mathrm{kg}$ C. borivilianum root extract treatment as compared to non-treated diabetic rats. Pancreatic MDA levels were nearly $44.54 \%$ lower in $500 \mathrm{mg} / \mathrm{kg} \mathrm{C}$. borivilianum root extract-treated diabetic rats as compared to non-treated diabetic rats. $48.04 \%$ lower MDA levels were observed in the pancreas of diabetic rats following glibenclamide treatment as compared to non-treated diabetic rats. The $500 \mathrm{mg} / \mathrm{kg}$ C. borivilianum root extract treatment was 1.06 time less potent than glibenclamide in preventing the increase in pancreas MDA levels in diabetic rats.

\section{Pancreas SOD Activity Levels}

The SOD activity levels in the pancreas of diabetic rats receiving $C$. borivilianum root extract or glibenclamide treatments were shown in figure 6B. Our findings indicate that SOD activity levels were $28.78 \%$ lower in STZ-induced diabetic rat as compared to normal, non-diabetic rats. 28-days treatment of diabetic rats with 250 and $500 \mathrm{mg} / \mathrm{kg} /$ day $C$. borivilianum root extract resulted in significantly higher SOD activity levels $(23.4 \%$ and $29.78 \%)$ as compared to non-treated diabetic rats. Glibenclamide administration resulted in $35.1 \%$ higher SOD activity levels as compared to non-treated diabetic rats. The $500 \mathrm{mg} / \mathrm{kg} \mathrm{C}$. borivilianum root extract was 0.96 time less potent than glibenclamide in preventing the increase in pancreas SOD activity levels in diabetes.

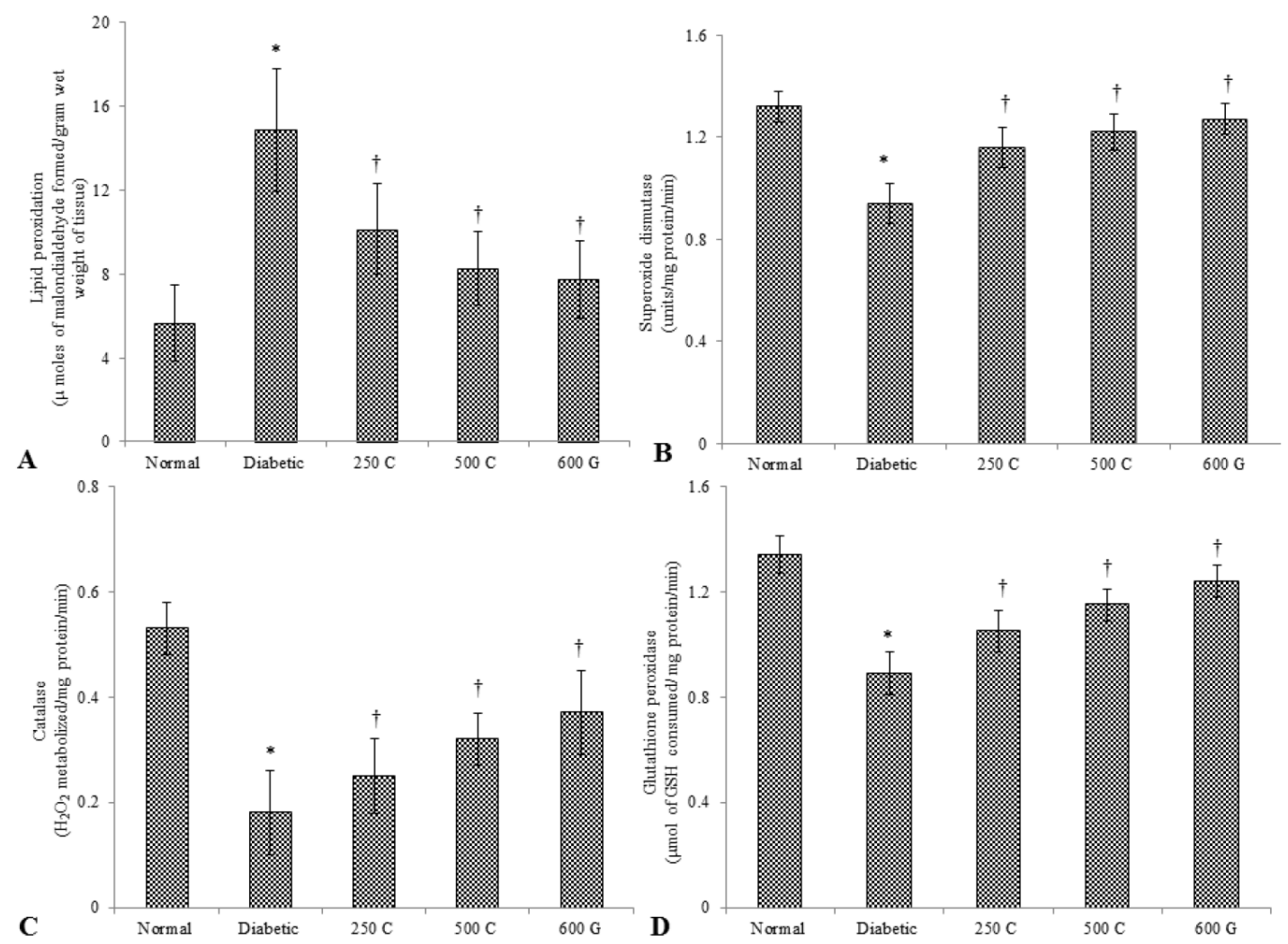

Figure 6: A) Estimation of LPO product, MDA in pancreas in different experimental groups. Higher MDA levels were noted in diabetic rats as compared to normal, non-diabetic rats. Administration of $C$. borivilianum root extract resulted in decreased MDA levels. B) SOD activity levels in pancreas in different experimental groups. SOD activity was reduced in diabetic rats as compared to normal, non-diabetic rats. Administration of $C$. borivilianum root extract at 250 and $500 \mathrm{mg} / \mathrm{kg} / \mathrm{day}$ or glibenclamide in diabetic rats resulted in higher SOD activity levels as compared to non-treated diabetic rats. C) CAT activity levels in pancreas in different experimental groups. Administration of $C$. borivilianum root extract at 250 and $500 \mathrm{mg} / \mathrm{kg} /$ day or glibenclamide in diabetic rats prevented the deterioration in CAT activity levels. D) GPx activity levels in pancreas in different experimental groups. Administration of $C$. borivilianum root extract at $250 \mathrm{and} 500 \mathrm{mg} / \mathrm{kg} / \mathrm{day}$ or glibenclamide prevented the deterioration of GPx activity in diabetes. $250 \mathrm{C}$ : $250 \mathrm{mg} / \mathrm{kg} /$ day C. borivilianum root extract; $500 \mathrm{C}: 500 \mathrm{mg} / \mathrm{kg} /$ day C. borivilianum root extract, $600 \mathrm{G}$ : $600 \mu \mathrm{gg} / \mathrm{kg} / \mathrm{day}$ glibenclamide. $\mathrm{n}=6 \mathrm{per}$ treatment group, ${ }^{*} \mathrm{p}<0.05$ as compared to normal, non-diabetic control rats, $\nmid \mathrm{p}<0.05$ as compared to non-treated diabetic rats. 


\section{Pancreas CAT Activity Levels}

Figure 6C shows the effect of $C$. borivilianum root extract or glibenclamide on pancreas CAT activity levels in diabetic rats. Our findings indicate that CAT activity levels were lower in diabetic rats $(66.03 \%)$, as compared to normal, non-diabetic rats. Treatment with 250 and $500 \mathrm{mg} / \mathrm{kg} /$ day C. borivilianum root extract in diabetic rats resulted in a significantly higher CAT activity levels (38.88\% and $77.77 \%)$ respectively as compared to non-treated diabetic rats. Glibenclamide treatment in diabetic rats resulted in $105.55 \%$ higher CAT activity levels as compared to non-treated diabetic rats. $500 \mathrm{mg} / \mathrm{kg} /$ day $C$. borivilianum root extract was 0.86 fold less potent than glibenclamide in preventing the increase in CAT activity levels in diabetes.

\section{Pancreas GPx Activity Levels}

Figure 6D shows the effect of $C$. borivilianum root extract or glibenclamide on GPx activity levels in diabetic rat pancreas. In non-treated diabetic rats, GPx activity levels were $33.58 \%$ lower than normal, non-diabetic rats. Treatment of diabetic rats with 250 $\mathrm{mg} / \mathrm{kg} /$ day C. borivilianum root extract resulted in $17.97 \%$ higher GPx activity levels as compared to non-treated diabetic rats. Meanwhile, $500 \mathrm{mg} / \mathrm{kg} /$ day C. borivilianum root extract treatment resulted in $29.21 \%$ higher GPx activity levels as compared to non-treated diabetic rats. Glibenclamide treatment resulted in 39.32\% higher GPx activity levels as compared to non-treated diabetic rats. $500 \mathrm{mg} / \mathrm{kg} /$ day $C$. borivilianum root extract was 0.92 fold less potent than glibenclamide in preventing the decrease in GPx activity levels in diabetic rat pancreas.

\section{Discussion}

To the best of our knowledge, this study is the first to investigate the effect of sub-chronic administration of $C$. borivilianum root aqueous extract on FBG, insulin, HbA1c and lipid profile levels, pancreas histolpathology, glucose homeostasis indices and pancreas oxidative stress in diabetes. We have shown that consumption of $C$. borivilianum root extract maintained near normal levels of FBG, insulin, $\mathrm{HbA1c}$, lipid profile, glucose homeostasis indices and prevented the destruction of normal pancreas morphology and the elevation of pancreas oxidative stress in diabetes. Our study complement and extent the previous observations in diabetic rodents where decrease in blood glucose levels were noted following acute administration of $C$. borivilianum root extract [13, 14]. In our study, high levels of FBG in STZ-induced diabetic rats could be due to the selective toxicity of this compound [9] towards pancreatic $\beta$-cell as indi- cated by reduced in the number of Islet of Langerhans and increased in signs of pancreatic inflammation. Administration of $C$. borivilianum or glibenclamide four days after STZ injection were able to rescue the pancreatic islet destruction and promote islet recovery therefore could lead to maintenance of near normal insulin secretion, levels of FBG, HbA1c and lipid profiles in diabetes. Similar observation has been reported in diabetic rats where glibenclamide administration seven days following STZ injection was able to reverse to near normal FBG and serum insulin levels [30].

There were reports which indicate ability of islets to recover following STZ injection. Bonner Weir et al [31] reported that administration of STZ to neonatal rats leads to partial islets recovery after 10 days and near full recovery in 6 weeks. Nicholson et al [32] reported that considerable amount of $\beta$-cell regeneration occurred following STZ exposure in rats. $\beta$-cells have been reported to display plasticity in adult mice, whereby $70-80 \%$ apoptosis and islets destruction following doxycline administration were reversed upon drug withdrawal [23, 33]. Meanwhile, a report in humans indicated that there was attempted regeneration of $\beta$-cells in newly onset type- 1 diabetes $[19,34]$. We postulated that $C$. borivilianum root extract was able to fasten $\beta$-cells regeneration and islets recovery following initial STZ insults, whereas slow or no recovery was anticipated in rats which did not received this extract treatment. Future study should take into consideration administration of this extract at the onset of STZ injection in order to investigate its protective role against STZ-induced $\beta$-cell toxicity. Additionally, protective effect of the extract against repeated STZ exposure should also be investigated.

In this study, higher insulin secretion in diabetic rats following $C$. borivilianum root extract treatment was reflected by higher HOMA- $\beta$ cell functioning index. HOMA $\beta$-cell functioning index is a valid [35] and widely used index to assess insulin secretion in diabetes [36-38]. Meanwhile, HOMA-insulin resistant (IR) index, a valid measure of insulin resistance [39, 40] was decreased following C. borivilianum root extract treatment which indicates decreased insulin resistance in diabetes. HOMA-IR index is a simple yet reliable measure of insulin resistance [41]. HOMA-IR index was comparable to other method for measuring insulin resistance such as hyperinsulinemic-euglycemic glucose clamp [42]. In our study, near normal HOMA $\beta$-cell functioning index following $C$. borivilianum root aqueous extract treatment was consistent with the morphometric analyses which indicate higher islets and $\beta$-cell numbers and diameters in diabetic rats receiving $C$. borivilianum root extract treatment. These findings pointed towards extract 
role in preventing pancreas destruction and maintaining pancreatic function in diabetes.

$\mathrm{HbA1c}$ is used to evaluate risk of developing micro- and macrovascular complications as well as to assess the cumulative damage due to hyperglycemia and glyco-oxidation in diabetes [43,44]. HbA1c is a sensitive marker which is used to detect early diabetes in high risk individuals with normal FBG levels [45]. $\mathrm{HbA1c}$ has also been used to monitor the glycemic control in order to assess the efficacy of diabetes treatment [46]. In our study, lower serum HbA1c levels which was observed in diabetic rats treated with $C$. borivilianum root aqueous extract indicate near normal glycemic control. We have shown that $C$. borivilianum root extract is as potent as glibenclamide, a reference anti-diabetic drug [47] in normalizing HbA1c levels indicating that this herb could potentially be used for a long-term control of blood glucose levels in diabetes. Further work to investigate the combined effect of glibenclamide and C. borivilianum root extract on FBG and $\mathrm{HbA} 1 \mathrm{c}$ levels in diabetic rats is needed to display superior effect of the combined treatment as compared to treatment with glibenclamide alone. Meanwhile, a strong negative correlation was observed between $\mathrm{HbA} 1 \mathrm{c}$ and serum insulin levels which indicate that changes of the former were dependent on the latter.

Our findings further showed that treatment with C. borivilianum root aqueous extract preserved near normal lipid profile levels in diabetic rats. $C$. borivilianum root extract has been reported to exhibit anti-hyperlipidemic and hypolipidemic effects [21]. Visavadiya and Narasimhacharya [48] reported that administration of C. borivilianum root to hypercholesterolemic, non-diabetic male rats resulted in a significant increase in plasma HDL levels and an improvement of plasma and hepatic lipid profile levels. We have shown that administration of $C$. borivilianum root extract was able to maintain near normal TC, TG, VLDL, LDL and HDL levels in diabetic rats. Preservation of near normal serum lipid profile levels could help to protect against hypercholesterolemia-induced cardiovascular complications including artherosclerosis and coronary artery disease [49] in view that hypercholesterolemia in diabetes is frequently associated with increased plasma LDL, TG with decreased HDL levels [50]. In addition, the increase insulin secretion as observed in diabetic rats treated with $C$. borivilianum root extract could help to normalize the lipid profile levels in view that insulin was found to inhibit TC [51] and TG [52] syntheses. In our study, negative correlation was observed between TG and TC with serum insulin levels which indicate that changes in serum lipid profiles was dependent on insulin.
Numerous studies have shown that hyperglycaemia can cause increased oxidative stress via activation of various molecular pathways including polyol, non-enzymatic protein glycosylation, glucose auto-oxidation and advanced glycation end products (AGES) accumulation which lead to increased production of ROS. In the present study, the amount of LPO product, MDA was higher in diabetic rats' pancreas as compared no non-diabetic rats indicating of high levels of oxidative stress due to intensified free-radical formation [53]. Our findings were in agreement with Kade et al [54] who reported that high amount of LPO product was observed in diabetic rats' pancreas. C. borivilianum root extract administration to diabetic rats lowered the LPO product, indicating that this plant extract could prevent elevation of oxidative stress of the pancreas in diabetes. This observation was supported by the reported in vivo and in vitro antioxidant activities of the root extract against tissue oxidative stress $[55,56]$.

Antioxidant enzymes such as SOD, CAT and GPx have been shown vital to eliminate ROS. SOD is one of the important enzymes that scavenges superoxide radical $\left(\mathrm{O}^{2 \cdot-}\right)$ to $\mathrm{H}_{2} \mathrm{O}_{2}$ and molecular oxygen [57]. In our study, SOD activity levels in diabetic rats' pancreas were decreased which could be due to inactivation by $\mathrm{H}_{2} \mathrm{O}_{2}$ or enzymatic glycosylation [58]. Meanwhile, CAT and GPx enzymes are involved in eliminating $\mathrm{H}_{2} \mathrm{O}_{2}$ and protect the tissue against highly reactive hydroxyl radicals. In our study, the decrease in CAT and GPx activity levels in diabetic rats' pancreas could be due to inactivation by superoxide radical or enzymatic glycation [59]. Administration of $C$. borivilianum root extract to diabetic rats prevented the parallel decrease in pancreas SOD, CAT and GPx activity levels. We proposed that the maintenance of near normal activity levels of these enzymes could help to protect tissue against oxidative damage caused by free radicals through enhancing the tissue antioxidative defense mechanisms [48]. Our findings were supported by similar observation in diabetic rats' liver where $C$. borivilianum root extract administration caused a simultaneous increase in activity levels of SOD, CAT and GPX and a decrease in the amount of MDA [60].

In our study, we postulated that maintenance of near normal body weight in diabetic rats following $C$. borivilianum root extract treatment may be related to the preservation of food intake or the protection against catabolism through increased insulin availability to promote the anabolic processes. In diabetes, loss of body weight could be due to increased muscle protein degradation [61]. In addition, diabetics were also reported to have decreased appetite [62] which could further aggravate weight loss. Insulin helps to 
restore body weight via stimulating protein [63] and lipid syntheses [64] as well as glycogen storage [65] in the skeletal muscles. Therefore, prevention against body weight loss in diabetic rats following $C$. borivilianum root extract treatment indicate that this herb may prevent the degradation of macromolecules and maintaining their storage in diabetes.

In conclusion, our findings has provided scientific evidences to support the claims that $C$. borivilianum root is useful in treating diabetes and its related metabolic complications via preserving near normal metabolite parameters including FBG, lipids and insulin levels and prevented the development of oxidative stress and the destruction of the pancreas in diabetes. These findings should be interpreted as the protective effect of the extract against STZ-induced progression of islets destruction. Additionally, this extract may also have insulinomimetic properties which may account for some of the observed insulin effects. Due to its high potency, C. borivilianum root extract could potentially be used in the treatment of diabetes and its metabolic complications.

\section{Acknowledgement}

This study was funded by High Impact Research Grant (UM.C/625/1/HIR/E000046-20001) University of Malaya, Kuala Lumpur, Malaysia.

\section{Conflict of Interest}

The authors reported no conflict of interest in this study.

\section{References}

1. Packard C, Olsson A. Management of hypercholesterolaemia in the patient with diabetes. Int J Clin Pract Suppl. 2002; :27-32.

2. Gouni-Berthold I, Krone W. Diabetic ketoacidosis and hyperosmolar hyperglycemic state. Medizinische Klinik (Munich, Germany: 1983). 2006; 101: 100-5.

3. Lambrinoudaki I, Tsouvalas E, Vakaki M, Kaparos G, Stamatelopoulos K, Augoulea A, et al. Osteoprotegerin, Soluble Receptor Activator of Nuclear Factor- $\mathrm{K}$ B Ligand, and Subclinical Atherosclerosis in Children and Adolescents with Type 1 Diabetes Mellitus. Int J Endocrinol. 2013; 2013: 8

4. Rajmohan L, Deepa R, Mohan A, Mohan V. Association between isolated hypercholesterolemia, isolated hypertriglyceridemia and coronary artery disease in south Indian type 2 diabetic patients. Indian Heart J. 2000; 52: 400-6.

5. Khan AS, Latif SU, Eloubeidi MA. Controversies in the etiologies of acute pancreatitis. JOP. 2010; 11: 545-52.

6. Saravanan G, Ponmurugan P. Ameliorative potential of S-allylcysteine: effect on lipid profile and changes in tissue fatty acid composition in experimental diabetes. Exp Toxicol Pathol. 2012; 64: 639-44.

7. Ramachandran B, Ravi K, Narayanan V, Kandaswamy M, Subramanian S. Protective effect of macrocyclic binuclear oxovanadium complex on oxidative stress in pancreas of streptozotocin induced diabetic rats. Chem Biol Interact. 2004; 149: 9-21.

8. Elosta A, Ghous T, Ahmed N. Natural products as anti-glycation agents: possible therapeutic potential for diabetic complications. Curr Diabetes Rev. 2012; 8: 92-108.

9. Rossini AA, Like AA, Chick WL, Appel MC, Cahill GF. Studies of streptozotocin-induced insulitis and diabetes. PNAS. 1977; 74: 2485-9.

10. Bandyopadhyay U, Das D, Banerjee RK. Reactive oxygen species: oxidative damage and pathogenesis. Current Science 1999. 77: 658-66.

11. Coskun O, Kanter M, Korkmaz A, Oter S. Quercetin, a flavonoid antioxidant, prevents and protects streptozotocin-induced oxidative stress and $\beta$-cell damage in rat pancreas. Pharmacol Res. 2005; 51: 117-23.

12. Khanam $Z$, Singh $O$, Singh $R$, Bhat IUH. Safed musli (Chlorophytum borivilianum): A review of its botany, ethnopharmacology and phytochemistry. J Ethnopharmacol. 2013; 150: 421-41.
13. anda SK, Si SC, Bhatnagar SP. Studies on Hypoglycaemic and Analgesic Activities of Chlorophytum borivilianum Sant \& Ferz. J Natu Remed. 2007; 7: 31 36.

14. Mujeeb M, Khan SA, Ali M, Mal A, Ahmad A. Antidiabetic activity of the aqueous extract of Chlorophytum borivilianum L. in Streptozotocin inducedhyperglycemic rats-a preliminary study. J Pharm Res. 2009; 2: 51-53.

15. Kenjale R, Shah RK, Sathaye SS. Anti-stress and anti-oxidant effects of roots of Chlorophytum borivilianum (Santa Pau \& Fernandes). Indian J Exp Biol. 2007; 45: 974-9.

16. Harborne AJ. Phytochemical Methods: A Guide to Modern Techniques of Plant Analysis 3, Revised ed: Springer; 1998

17. OECD. Organisation for Economic and Cultural Development: Guidelines for Testing Chemicals, Acute Oral Toxicit up and down Procedure. 2001; 425: 1-26.

18. Teixeira DC, Farias DF, Carvalho AFU, Arantes MR, Oliveira JT, Sousa DO et al. Chemical Composition, Nutritive Value, and Toxicological Evaluation of Bauhinia cheilantha Seeds: A Legume from Semiarid Regions Widely Used in Folk Medicine. BioMed Research International 2013; 2013: 7

19. Konaté K, Bassolé IHN, Hilou A, Aworet-Samseny RR, Souza A, Barro N, et al. Toxicity assessment and analgesic activity investigation of aqueous acetone extracts of Sida acuta Burn f. and Sida cordifolia L.(Malvaceae), medicinal plants of Burkina Faso. BMC Complement Altern Med. 2012; 12: 120

20. Nelli GB, K AS, Kilari EK. Antidiabetic effect of a-mangostin and its protective role in sexual dysfunction of streptozotocin induced diabetic male rats. Syst Biol Reprod Med. 2013; 59: 319-28.

21. Visavadiya N, Narasimhacharya A. Ameliorative effect of Chlorophytum borivilianum root on lipid metabolism in hyperlipaemic rats. Clin Exp Pharmacol Physiol. 2007; 34: 244-9.

22. Kumar M, Prasad SK, Krishnamurthy S, Hemalatha S. Antihyperglycemic Activity of Houttuynia cordata Thunb. in Streptozotocin-Induced Diabetic Rats. Adv Pharmacol Sci. 2014; 2014: 12

23. Ezejiofor AN, Okorie A, Orisakwe OE. Hypoglycaemic and tissue-protective effects of the aqueous extract of Persea americana seeds on alloxan-induced albino rats. The Malaysian journal of medical sciences: MJMS. 2013; 20: 31

24. Friedewald WT, Levy RI, Fredrickson DS. Estimation of the concentration of low-density lipoprotein cholesterol in plasma, without use of the preparative ultracentrifuge. Clinical Chemistry. 1972; 18: 499-502.

25. Matthews D, Hosker J, Rudenski A, Naylor B, Treacher D, Turner R. Homeostasis model assessment: insulin resistance and $\beta$-cell function from fasting plasma glucose and insulin concentrations in man. Diabetologia. 1985; 28: $412-9$

26. Esterbauer $\mathrm{H}$, Cheeseman $\mathrm{KH}$. Determination of aldehydic lipid peroxidation products: Malonaldehyde and 4-hydroxynonenal. In: Lester Packer ANG, editor. Methods in Enzymology. Academic Press. 1990: 407-21.

27. Misra HP, Fridovich I. The role of superoxide anion in the autoxidation of epinephrine and a simple assay for superoxide dismutase. J Biol Chem. 1972; 247: 3170-5

28. Bonaventura J SW, Fang S. Human erythrocyte catalase: an improved method of isolation and a reevaluation of reported properties. Arch Biochem Biophys. 1972; 150: 606-17.

29. Rotruck JT PA, Ganther HE, Swanson AB, Hafeman DG, Hoekstra WG. Selenium: biochemical role as a component of glutathione peroxidase. Science. 1973; 179: 588-90.

30. Hafizur RM, Babiker R, Yagi S, Chishti S, Kabir N, Choudhary MI. The antidiabetic effect of Geigeria alata is mediated by enhanced insulin secretion, modulation of $\beta$-cell function, and improvement of antioxidant activity in streptozotocin-induced diabetic rats. J Endocrinol. 2012; 214: 329-35.

31. Bonner-Weir S, Trent D, Honey R, Weir G. Responses of neonatal rat islets to streptozotocin: limited $\beta$-cell regeneration and hyperglycemia. Diabetes. 1981; 30: 64-9.

32. Nicholson JM, Arany EJ, Hill DJ. Changes in islet microvasculature following streptozotocin-induced $\beta$-cell loss and subsequent replacement in the neonatal rat. Exp Biol Med (Maywood). 2010; 235: 189-98.

33. Nir T, Melton DA, Dor Y. Recovery from diabetes in mice by $\beta$ cell regeneration. J Clin Invest. 2007; 117: 2553-61.

34. Meier J, Lin J, Butler A, Galasso R, Martinez D, Butler P. Direct evidence of attempted beta cell regeneration in an 89 -year-old patient with recent-onset type 1 diabetes. Diabetologia. 2006; 49: 1838-44

35. Conwell LS, Trost SG, Brown WJ, Batch JA. Indexes of insulin resistance and secretion in obese children and adolescents: a validation study. Diabetes Care. 2004; 27: 314-9.

36. Festa A, Williams K, Hanley AJ, Haffner SM. $\beta$-cell dysfunction in subjects with impaired glucose tolerance and early type 2 diabetes comparison of surrogate markers with first-phase insulin secretion from an intravenous glucose tolerance test. Diabetes. 2008; 57: 1638-44.

37. Li Y, Zhu D, Tian H, Shi L, Luo Z, Yan L, et al. Characteristics of dysfunction of islet beta-cell in newly diagnosed type 2 diabetic patients. Zhonghua yi xue za zhi. 2006; 86: 2537-41.

38. Liu J, Li Y, Shao H, Li Y, Yuan Y, Xiao Y, et al. Evaluation of islet beta cell function in subjects with normal glucose tolerance, impaired glucose regulation, and type 2 diabetes mellitus. Zhonghua yi xue za zhi. 2007; 87: 1252-5.

39. Sun M, Huang X, Jiang L, Yan Y, Li B, Zhong W, et al. Characterization of $\beta$-cell function and insulin resistance in overweight Chinese adolescents with normal glucose tolerance. Exp Ther Med. 2013; 6: 547-51.

40. Yin J, Li M, Xu L, Wang Y, Cheng H, Zhao X, et al. Insulin resistance determined by Homeostasis Model Assessment (HOMA) and associations with 
metabolic syndrome among Chinese children and teenagers. Diabetol Metab Syndr. 2013; 5: 71.

41. Keskin M, Kurtoglu S, Kendirci M, Atabek ME, Yazici C. Homeostasis model assessment is more reliable than the fasting glucose/insulin ratio and quantitative insulin sensitivity check index for assessing insulin resistance among obese children and adolescents. Pediatrics. 2005; 115: e500-e3.

42. Ntyintyane L, Panz V, Raal F, Gill G. Comparison between surrogate indices of insulin sensitivity and resistance, and the hyperinsulinaemic euglycaemic glucose clamp in urban South African blacks with and without coronary artery disease. Diab Vasc Dis Res. 2010; 7: 151-7.

43. Monnier VM, Sell DR, Genuth S. Glycation Products as Markers and Predictors of the Progression of Diabetic Complications. Ann N Y Acad Sci. 2005; 1043: 567-81.

44. Lyons TJ, Basu A. Biomarkers in diabetes: hemoglobin A1c, vascular and tissue markers. Transl Res. 2012; 159: 303-12.

45. Perry RC, Shankar RR, Fineberg N, McGill J, Baron AD. HbA1c Measurement Improves the Detection of Type 2 Diabetes in High-Risk Individuals With Nondiagnostic Levels of Fasting Plasma Glucose: The Early Diabetes Intervention Program (EDIP). Diabetes Care. 2001; 24: 465-71.

46. Wu JT. Review of diabetes: identification of markers for early detection, glycemic control, and monitoring clinical complications. J Clin Lab Anal. 1993; 7: 293-300.

47. Vicent D, Garcia-Martinez JA, Villanueva-Peñacarrillo ML, Valverde I, Malaisse WJ. Stimulation of insulin secretion and potentiation of glibenclamide-induced insulin release by the dimethyl ester of glutamic acid in anaesthetized rats. Diabetes Res Clin Pract. 1995; 27: 27-30.

48. Visavadiya NP, Narasimhacharya A. Ameliorative effects of herbal combinations in hyperlipidemia. Oxid Med Cell Longev. 2011.

49. Chen S, Tseng C. Dyslipidemia, kidney disease, and cardiovascular disease in diabetic patients. The review of diabetic studies: RDS. 2012; 10: 88-100.

50. obrovolskienė R, Mockevičienè G, Urbonaitė B, Jurgevičienė N, Preikša RT, Ostrauskas R. The risk of early cardiovascular disease in Lithuanian diabetic children and adolescents: A type 1 diabetes register database based study. Diabetes Res Clin Pract. 2013; 100: 119-25.

51. Naoumova R, Cummings M, Watts G, Rendell N, Taylor G, Sönksen P, et al Acute hyperinsulinaemia decreases cholesterol synthesis less in subjects with non-insulin-dependent diabetes mellitus than in non-diabetic subjects. Eur J Clin Invest. 1996; 26: 332-40.

52. Malmström R, Packard CJ, Caslake M, Bedford D, Stewart P, Yki-Järvinen H, et al. Defective regulation of triglyceride metabolism by insulin in the liver in NIDDM. Diabetologia. 1997; 40: 454-62.

53. Anwar MM, Meki AR. Oxidative stress in streptozotocin-induced diabetic rats: effects of garlic oil and melatonin. Comp Biochem Physiol A Mol Integr Physiol. 2003; 135: 539-47.

54. Kade IJ OY, Kamdem JP, Rocha JB. Influence of gallic acid on oxidative stress-linked streptozotocin-induced pancreatic dysfunction in diabetic rats. J Basic Clin Physiol Pharmacol. 2013;: 1-11.

55. Govindarajan R, Sreevidya N, Vijayakumar M, Thakur M, Dixit V, Mehrotra S, et al. In vitro antioxidant activity of ethanolic extract of Chlorophytum borivilianum. Nat Prod Sciences. 2005; 11

56. Kenjale R, Shan R, Sathaye S. Anti-stress and anti-oxidant effects of roots of Chlorophytum borivilianum (Santa Pau \& Fernandes). Indian J Exp Biol. 2007; 45: 974.

57. Vincent AM, Russell JW, Low P, Feldman EL. Oxidative stress in the pathogenesis of diabetic neuropathy. Endocr Rev. 2004; 25: 612-28.

58. Ravi K, Ramachandran B, Subramanian S. Protective effect of Eugenia jambolana seed kernel on tissue antioxidants in streptozotocin-induced diabetic rats. Biol Pharm Bull. 2004; 27: 1212-7.

59. Rajasekaran S, Sivagnanam K, Subramanian S. Antioxidant effect of Aloe vera gel extract in streptozotocin-induced diabetes in rats. Pharmacol Rep. 2005; 57: 90-6.

60. Sharma G, Kumar M. Antioxidant and modulatory role of Chlorophytum borivilianum against arsenic induced testicular impairment. Journal of Environmental Sciences. 2012; 24: 2159-65.

61. Hu Z, Lee IH, Wang $\mathrm{X}$, Sheng $\mathrm{H}$, Zhang L, Du J, et al. Pten expression contributes to the regulation of muscle protein degradation in diabetes. Diabetes. 2007; 56: 2449-56.

62. Russell AW, Horowitz M, Ritz M, MacIntosh C, Fraser R, Chapman IM. The effect of acute hyperglycaemia on appetite and food intake in type 1 diabetes mellitus. Diabet Med. 2001; 18: 718-25.

63. Timmerman KL, Lee JL, Dreyer HC, Dhanani S, Glynn EL, Fry CS, et al. Insulin Stimulates Human Skeletal Muscle Protein Synthesis via an Indirect Mechanism Involving Endothelial-Dependent Vasodilation and Mammalian Target of Rapamycin Complex 1 Signaling. J Clin Endocrinol Metab. 2010; 95: 3848-57.

64. Heydrick SJ, Ruderman NB, Kurowski TG, Adams HB, Chen KS. Enhanced stimulation of diacylglycerol and lipid synthesis by insulin in denervated muscle: altered protein kinase $\mathrm{C}$ activity and possible link to insulin resistance. Diabetes. 1991; 40: 1707-11.

65. Dent P, Lavoinne A, Nakielny S, Caudwell FB, Watt P, Cohen P. The molecular mechanism by which insulin stimulates glycogen synthesis in mammalian keletal muscle. Nature $1990 ; 348 \cdot 302-8$. 